DE DE GRUYTER OPEN
Research Article

(C) 2018 Salim et.al. This is an open access article licensed under the Creative Commons Attribution-NonCommercial-NoDerivs License (http://creativecommons.org/licenses/by-nc-nd/3.0/).

\section{Dispute Resolution in the Implementation of Mining Exploration in Sumbawa}

\author{
Salim HS $^{1}$ \\ I Nyoman Nurjaya ${ }^{2}$ \\ Muhammad Bakri \\ Anang Husni ${ }^{1}$ \\ ${ }^{1}$ Faculty of Law, Mataram University - Mataram, Indonesia \\ ${ }^{2}$ Faculty of Law, Brawijaya University - Malang, Indonesia
}

Doi: $10.2478 / \mathrm{mjss}-2018-0082$

\title{
Abstract
}

The present study aims to comprehensively describe, interpret, and analyze (1) factors causing the dispute between people of Labangkar and Ropang Village, Ropang District, Sumbawa Regency and PT Newmont Nusa Tenggara, and (2) the pattern of dispute resolution between people of Labangkar and Ropang Village, Ropang District, Sumbawa Regency and PT Newmont Nusa Tenggara. The study focused on empirical legal research and implemented legal anthropology as the approach. This study was conducted at Ropang and Labangkar Village, Ropang District, Sumbawa Regency. It used 12 people as sample. The data were analyzed qualitatively. Primary data were collected through in-depth interview with respondents using interview guides and a tape recorder as the instrument. Secondary data were obtained by collecting documents, such as the agreements which have been made by the parties, the status of Elang Dodo forest area, as well as the history of the land in Elang Dodo.

Keywords: Dispute resolution, exploration, mining

\section{Introduction}

Sumbawa is a regency that is rich in mineral resources, including gold, copper, silver, and manganese. Sumbawa people call Sumbawa as Tana Bulaeng. Tana Bulaeng is a Sumbawa language refers to land containing 24-carat gold. The mineral resources spread across several districts, one of which is Elang Dodo. Although Sumbawa has potential mineral resources, Sumbawa Government has not been able to manage and exploit the mineral resources well. As the result, the Government appointed other parties to carry out mining activities. One of the parties appointed by the Government is PT Newmont Nusa Tenggara, which is now owned by PT Amman Mineral Nusa Tenggara.

PT Newmont Nusa Tenggara has been conducting exploration in Elang Dodo area since 2004. Philosophically, the purpose of exploration activities is to improve the welfare of the community, while the purpose of dispute resolution is to bring back the relationship of the parties, i.e. the people of Labangkar and Ropang and PT Newmont Nusa Tenggara, in a state as before.

\section{Research Method}

The study focused on empirical legal research and implemented legal anthropology as the approach. This study was conducted at Ropang and Labangkar Village, Ropang District, Sumbawa 
Regency. It used 12 people as sample. The data were analyzed qualitatively. Primary data were collected through in-depth interview with respondents using interview guides and tape recorder as the instrument. Secondary data were obtained by collecting documents, such as the agreements which have been made by the parties, the status of Elang Dodo forest area, as well as the history of the land in Elang Dodo.

\section{Results and Discussion}

\subsection{Empirical Analysis of the Causes of Dispute between Labangkar and Ropang People and PT Newmont Nusa Tenggara}

Mining exploration conducted by PT Newmont Nusa Tenggara in Elang Dodo area has caused disputes between people of Labangkar and Ropang and PT Newmont Nusa Tenggara. The results showed there are five factors causing the dispute between them, which are: (1) tana balo tolo of Labangkar people has not been acknowledged, (2) compensation for tana balo tolo has not meet the demand; (3) some of Ropang people have not been employed at PT Newmont Nusa Tenggara, (4) proposal for the development of society has not been fulfilled, and (5) lack of socialization (Salim, 2012). These five causes will be briefly explicated below.

\subsubsection{Villagers' Reasons for Requesting Recognition for Tana Balo Tolo}

The emergence of dispute between the villagers of Labangkar and Ropang Village and PT Newmont Nusa Tenggara is because Sumbawa Government has not formally recognized tana balo tolo of Labangkar people located in Elang Dodo. Tana balo tolo is defined as a land left by parents, grandparents, and ancestors to Labangkar people.

The investigation team found evidences, such as former ghetto, plants, fields, gardens and cemeteries of Dodo community. Supposedly, by the presence of these findings, the Regent of Sumbawa would consider to recognize the existence of tana balo tolo in Elang Dodo. However these evidences were not deemed sufficient by the team to recognize the rights of people who are in Elang Dodo, for the team tended to use formal proof. It is mentioned in the joint statement between the people of Labangkar with the Investigation Team that:

"The team could not prove clearly the strong right basis to the recognition of land tenure, but the team expects the real effort of the community, as expressed by the investigation team, to be considered for awards".

The substance of joint statement that was made between the representatives of Sumbawa Government and the people residing in the area around Elang Dodo is dualism, because, on the other hand, the investigation team could not prove clearly the strong right basis. However, the agreement has approved to reward community efforts proved significantly in the field.

When "the real effort of the community .... to be considered for award" refers to the representatives of Sumbawa government and society that follows the meeting, it is explicitly clear that the Government acknowledge the fact that the land used by PT Newmont Nusa Tenggara is tana balo tolo of Labongkar people. In addition, the people of Labongkar still consider the land used by PT Newmont Nusa Tenggara as their tana balo tolo. Proof used by Labangkar people to the contract work area of PT Newmont Nusa Tenggara is based on factual or physical evidence that they used to be the heirs of the tau (people) of Dodo. Physical evidences presented by Labangkar people were enormous walls of former mosque at Dodo, beduk (traditional drum made from leather), tomb, and plants, such as coconut trees, palm, teak, walnut, betel, jackfruit, star fruit, and lemon.

Based on the above explanation, it can be argued that the land of Labangkar people located in Elang Dodo needs to be recognized de facto. In addition, most of the people are still relying their life on Elang Dodo area.

Although there are factual evidences showing the ownership of tana balo tolo, Sumbawa Government has not given a formal recognition of the rights to Labongkar people. 


\subsubsection{Provision of Indemnity}

Forms of indemnity that may be requested (Asser's, 1988) by the injured party are:

1. Material indemnity; and

2. Immaterial indemnit.

Material loss is a loss suffered by the community in the form of money/wealth/objects. On the other hand, immaterial loss is a loss suffered by people who are not worth the money, such as pain, pale face, and others.

In the Circular of the Minister of Forestry Number: S.75/Menhut-II/2004 on the Issues of Customary Law and Compensation Demands/Indemnity by Indigenous and Tribal Peoples, dated March 12, 2004, indemnity to the charges filed by the customary law community has been determined. There are two things mentioned in the Circular of the Minister of Forestry Number: S.75/Menhut II/200, which are:

1. The form of indemnity; and

2. The role of local governments.

The forms of indemnity proposed by the Ministry of Forestry are:

1. A new livelihood;

2. Involvement in the surrounding forest utilization; or

3. Construction of public/social facilities beneficial to the customary law community.

Meanwhile, the role of the governor or regent/mayor is to facilitate meetings between indigenous people and concessionaires of HPH/IUPHHK. The purpose of the meeting is to resolve the demands of indigenous and customary law community to concessionaires of HPH/IUPHHK.

The form of indemnity agreed by the investigation team, BPD, village chiefs, and community leaders throughout Lantung and Ropang district was given in communal compensation. However, the agreement signed on September 4, 2004 in Bappeda of Sumbawa was not approved by community representatives of Labangkar. The representatives who followed the meeting consist of Mstkm and Ung. At the time of formulating the form of indemnity, community representatives of Labangkar staged walkout from the boardroom. What is expected by the representatives is not a communal compensation, but the compensation granted to individuals who have land in Elang Dodo, in which it was discussed in tokal barema (seated together) with the entire community of Labangkar. Therefore, they kept fighting for the rights of the people they represent.

Forms of indemnity agreed between the investigation team, village heads, and chairmen of BPD of Ropang District were already based on the legislation in force. It is mentioned in Article 14 of Presidential Decree Number 36 of 2005 on Land Procurement for Implementation of Development for Public Interest that:

"Replacement of the field controlled by customary rights is granted in the form of construction of public facilities or other forms that are beneficial to the community throughout the place".

Basically, indemnity in the form of communal and infrastructure is the most appropriate indemnity, for all facilities that will be built later by PT Newmont Nusa Tenggara will be enjoyed by all people in Ropang District, for example, the construction of road.

\subsubsection{Labor}

This provision requires that PT Newmont Nusa Tenggara in producing goods and services should employ:

1. Indonesian labor;

2. Services; and

3. Raw materials produced from Indonesian sources.

Labor can be divided into three types; (1) local, (2) national, and (3) foreign labor. Local labor is labor that comes from communities live nearby the company. National labor is labor that comes from all corners of Indonesia. Foreign labor is labor coming from abroad. In Article 17 paragraph (3) KK Generation VII, it is determined that local labor receive a very large portion for working in the mine. This is intended to avoid disputes between the communities around the mine with the company.

Given the fact on the quality of local people, the company would not employ local people 
because they have a weakness, which is the lack of capacity and expertise in the field of mining.

The respondents were expecting that the share of local labor to work on the mining company must be greater than the national and local labor, i.e. $60 \%$ of the workforce living nearby the company and $40 \%$ labor from outside. However, what used to be questionable is the village or district that can be classified as local communities. Usually a company, particularly mining company, maps the region covering the area around the mine covering three or four districts. The region around the mines is a priority to hire labor on mining companies. The purpose of this recruitment is to avoid disputes between the company and the community.

\subsubsection{Rejection of Proposal}

One of the causes of dispute between Ropang people and PT Newmont Nusa Tenggara is the proposal submitted by Ropang people to PT Newmont Nusa Tenggara which was not accepted. Rp10 billion was budgeted in the proposals initiated by Arief Perdana Kusuma (PT Newmont Nusa Tenggara) and district head of Lenangguar (Drs. Sulaiman). The purpose of proposing Rp10 billion was to improve the welfare of Ropang people who were not employed at PT Newmont Nusa Tenggara. That amount of money would be used to: (1) develop the village, such as building village drainage, (2) improve local economy, such as trading, (3) raise cattle, and (4) grow vegetables.

Although PT Newmont Nusa Tenggara asked the villagers to make proposals, they would not be approved by PT Newmont Nusa Tenggara, on the grounds that the activity will be carried out in the exploratory stage. At the moment, PT Newmont Nusa Tenggara was going to pay out a huge amount of money to conduct exploration activities. Meanwhile, the people living around the area of Elang Dodo expected PT Newmont Nusa Tenggara to perform activities of social responsibility, not only in exploitation phase, but also during the exploration stage. Since the request is not fulfilled, the people burnt the base camp of PT Newmont Nusa Tenggara in Elang Dodo on March 19, 2006.

\subsubsection{Lack of Socialization}

Another cause of the emergence of dispute is the lack of socialization conducted by PT Newmont Nusa Tenggara to the people of Labangkar and Ropang. PT Newmont Nusa Tenggara has conducted exploration activities in Elang Dodo since 2004 without giving notification to the community. Labangkar people knew the activity after having been informed by Lantung people. To prevent disputes between communities and PT Newmont Nusa Tenggara, socialization to public should be conducted.

\subsection{Resolution Patterns of the Dispute between the People of Labongkar and PT Newmont Nusa Tenggara}

In the customary law of Sasak people, it is known institutions and values of local wisdom related to traditional dispute resolution. The competent institutions to resolve the dispute in Sasak people is kerama gubuk or majelis pemusungan (Abdullah, 2020). Kerama gubuk is a customary institution consists of formal leader (head of the village/keliang and the members) as well as non-formal leaders (religious leaders, traditional leaders, and intellectuals). This term is known in Lombok community, especially in East Paresak. Sasak people also have pemusungan institution, or majelis pemusung. Pemusungan institution, or majelis pemusung, is a local authority under the control of indigenous stakeholders, Bayan. The main function of the institutions for Sasak people is to discuss policies with regard to custom cases that arise, among others: (1) customary marriage ("merari", or "elope"), (2) adultery, (3) inheritance, and (4) other customary violations which can cause interference on the balance of social life.

Resolution of disputes through traditional institutions is also known in Samawa community. It is stated in Article 6 paragraph (2) of Sumbawa Regency Regulation No. 23 of 2007 concerning Traditional Institution set on August 1, 2007. It regulates the tasks of traditional institutions, which are to:

1. Be a facilitator and mediator in the resolution of disputes relating to customs and habits of the people; 
2. Empower, develop, and preserve the customs and habits of the people in order to enrich local culture as an integral part of national culture; and

3. Create a democratic and harmonious relationship and objectivity among traditional leaders, traditional authorities, traditional leaders, and government officials at all levels in Sumbawa.

The main task of tana Samawa traditional institutions are regulating, managing, and resolving various problems of life related to customs and customary law of tana Samawa. Law used to solve the problem is the customary laws of tana Samawa. Tana Samawa customary law is the applicable law for the tau (people) of Samawa. In deciding any disputes, the traditional institutions of tana Samawa are based on the value "Adat Ketong Syara, ke Syara Ketong Kitabullah". This means that the prevailing custom is based on Syara (Islamic law) and Syara is based on Kitabullah (the Quran). The philosophy used in traditional institutions of tana Samawa in deciding an issue is "Krik selamat tau ke tana Samawa, taket ko Nene, kangila boat lenge".

In the above symbol, it is not clearly stated the ways of resolving disputes that are used by the people of Samawa. Based on this research, it has been found several terms related to ways of resolving disputes in the community of Samawa, including (1) tumaq barema, (2) tumaq basuan, (3) saling basabalong, (4) basasai, (5) yasasapah, and (6) basaterang (Salim, 2012).

Of the various terms above, there are three ways of dispute resolution expected to resolve the dispute between Labangkar people and PT Newmont Nusa Tenggara. Those three ways are: (1) tumaq barema or tumaq basuan or tokal barema, (2) negotiations, and (3) mediation.

The purpose of tumaq barema or tumaq basuan or tokal barema is to formulate the wishes of Labangkar people to PT Newmont Nusa Tenggara. For example, in each tumaq barema or tumaq basuan or tokal barema, what is needed by Labangkar people are:

1. Recognition of their tana balo tolo land in Elang Dodo; and

2. Request for compensation for the their tana balo tolo.

From the results of this joint sitting, the public appointed their representatives to fight for their rights. Representatives appointed by the society did not ask directly ask PT Newmont Nusa Tenggara, but they asked Sumbawa Government to fight for their rights to PT Newmont Nusa Tenggara. The results of tokal barema were submitted by the representative of Labangkar people to Sumbawa Regency government. Who acted as representatives of Labangkar are Mstkm and Ung. Based on the request of the representatives, Sumbawa Regency Government held a meeting on September 4, 2004. One of the results of the meeting is:

"Compensating communally (in the form of public interest) the people, whose land within the exploration area of PT Newmont Nusa Tenggara, but not given to an individual or individuals".

The agreement that was reached on September 4, 2004 is expected to be delivered to PT Newmont Nusa Tenggara, for the people considered government, in particular the Regent, as the father of customary law of Labangkar, who would fight for their rights. However, in reality the results of the meeting were never delivered to PT Newmont Nusa Tenggara, so that PT Newmont Nusa Tenggara was engaged in community development in the area of Batu Hijau, West Sumbawa. Meanwhile, PT Newmont Nusa Tenggara in Ropang solely built a health center, while other infrastructures in Ropang have not been established.

Seen from the theoretical aspect, dispute resolution through institutions that live and thrive in society is allowed. This is apparent from the model of dispute settlement offered by Dean G. Pruitt and Jeffrey Z., Rubin and Laura Nader, and Harry F. Todd, Jr.. Dean G. Pruitt and Jeffrey Z. Rubin suggested five strategies for dispute resolution, which include (1) contending (trying to implement a solution that is preferred by one party to the other party), (2) yielding (reducing the aspiration and willing to accept less than what is actually desired), (3) problem solving (looking for alternatives that satisfy the aspirations of both parties), (4) withdrawing (choosing to leave situations of dispute, both physically and psychologically), and (5) inaction (not doing anything).

Of the five ways of dispute resolution, what is suitable with the expectation of Labangkar people is using problem solving. They expect that their tana balo tolo problem in Elang Dodo with PT Newmont Nusa Tenggara can be solved. 
In addition, negotiation and mediation are suitable for the dispute resolution. Negotiation was done by Labangkar people to formulate their expectations and will. The results of these negotiations were submitted to Sumbawa Regent. Sumbawa Regent was asked by them to resolve the disputes with PT Newmont Nusa Tenggara, for Sumbawa Regent is considered as the father of their customary law. Sumbawa Regent, in the dispute, becomes the mediator. In fact, PT Newmont Nusa Tenggara also asked Sumbawa Regent to resolve any issues related to implementation of exploration activities in Elang Dodo.

\section{Conclusion and Recommendation}

\subsection{Conclusion}

From the above explanation, it can be concluded that:

a. Factors causing disputes between the people of Labangkar and Ropang and PT Newmont Nusa Tenggara are (1) Balo tolo land which has not been acknowledged by Sumbawa Government and PT Newmont Nusa Tenggara, (2) indemnity for balo tolo land that has not met the demand; (3) some of Ropang people who were employed by PT Newmont Nusa Tenggara, (4) rejection of proposal for the development of society, and (5) lack of socialization

b. The pattern of land dispute resolution expected by the people of Labangkar and Ropang is tuma barema or tuma basuan or tokal barema or barembuq with PT Newmont Nusa Tenggara. However, they expected the active involvement of Sumbawa Government in facilitating settlement of land disputes with PT Newmont Nusa Tenggara.

\subsection{Recommendations}

a. Sumbawa Government and PT Newmont Nusa Tenggara should recognize de facto and provide compensation for tana balo tolo of Labangkar people, located in Elang Dodo, Ropang, Sumbawa.

b. It is needed to use traditional institutions in the resolution of disputes arising in society, either between communities or between the community and the government.

\section{References}

Abdullah, I. (2002). Penyelesaian Sengketa Melalui Mekanisme Pranata Lokal, Studi Kasus dalam Dimensi Pluralisme Hukum Pada Area Suku Sasak di Lombok Barat. Postgraduate Program Dissertation of Indonesia University.

Abdurrasyid, P. (2002). Arbitrase \& Alternatif Penyelesaian Sengketa Suatu Pengantar. Jakarta: PT Fikahati Aneska in corporation with Badan Arbitrase Nasional Indonesia (BANI).

Alexander, P. (1999). Alternative Dispute Resolution Practitioners Guide, Washington, DC: Democracy and Governance Bureau for Democracy, Conflict, and Humanitarian Assistance U.S. Agency for International Development.

Asser's. (1998). Pengajian Hukum Perdata Belanda. Translated by Sulaeman, Jakarta: Dian Rakyat.

Friedman, L.M. (2001). American Law an Introduction (Hukum Amerika: Sebuah Pengantar). Translated by Wisnu Basuki. Jakarta: PT Tata Nusa.

Kriekhoff, V.J.L. (2001). Mediasi (Tinjauan Dari Segi Antropologi Hukum). Jakarta: Yayasan Obor.

Peter, AAG. and Siswosobroto, (ed). (1988). Hukum dan Pembangunan Sosial. Buku Teks Sosiologi Hukum (Buku I), (Jakarta: Sinar Harapan.

Pruitt, D.G. and Jeffrey Z. R. (2004). Konflik Sosial. Yogyakarta: Pustaka Pelajar.

Salim H.S. (2012). Penyelesaian Sengketa Tanah di Wilayah Kontrak Karya PT Newmont Nusa Tenggara (Studi Kasus Sengketa antara Masyarakat Desa Labangkar dan Desa Ropang, Kecamatan Ropang, Kabupaten Sumbawa dengan PT Newmont Nusa Tenggara). Dissertation of Faculty of Law Brawijaya University, Malang.

Ritzer, G. and Douglas J.G. (2007). Teori Sosiologi Modern (Modern Sociological Theory). Translated by Alimandan. Jakarta: Prenada.

Taufik, I. (2007). Relasi Negara dan Masyarakat dalam Diskursus Sengketa di Indonesia dalam Mengelola Sengketa Membangun Damai Teori, Strategis dan Implementasi Resolusi Sengketa. Semarang: WMC (Walisongo Mediation Center) and IAIN Walisongo. 